\title{
Large- and Medium-Sized Land Mammals of Northeast Marajó Island, Lower Amazon, Brazil
}

\author{
Salvatore Siciliano1,2, Renata Emin-Lima ${ }^{3}$, Alexandra F. Costa ${ }^{3,4}$, \\ José de Sousa e Silva Júnior ${ }^{3}$ \\ ${ }^{1}$ Escola Nacional de Saúde Pública/FIOCRUZ, Rio de Janeiro, RJ, Brazil \\ ${ }^{2}$ Instituto Megafauna Marinha, Cabo Frio, Brazil \\ ${ }^{3}$ Museu Paraense Emílio Goeldi, Coordenação de Zoologia, Setor de Mastozoologia and Grupo de Estudos de \\ Mamíferos Aquáticos da Amazônia (GEMAM), Belém, PA, Brazil \\ ${ }^{4}$ PPG em Ecologia Aquática e Pesca, Instituto de Ciências Biológicas, Universidade Federal do Pará-UFPA, \\ Belém, PA, Brazil \\ Email: gemmlagos@gmail.com
}

Received 2 January 2015; accepted 20 January 2015; published 26 January 2015

Copyright (C) 2015 by authors and Scientific Research Publishing Inc.

This work is licensed under the Creative Commons Attribution International License (CC BY). http://creativecommons.org/licenses/by/4.0/

(c) (i) Open Access

\begin{abstract}
Marajó, located in the lower Amazon, Brazil, is one of the largest river islands in the world. Most of the island is subject to tidal or seasonal flooding. Despite its historical, cultural and geographical importance, Marajó Island remains relatively less investigated in terms of mammal diversity, ecology and community structure than the rest of the Amazon. This scenario has motivated the presentation of this list of land mammals of eastern Marajó Island. Two field surveys were conducted in the course of 7-11 December 2012 and 17-25 October 2013 in Jaranduba, Dunas and Ribanceira Farms, northeast portions of Marajó Island. A total of 23 large and medium-sized land mammal species were recorded in the study area. These farms host a representative mammal community of northeastern Marajó, an area lacking previous faunal studies. Human pressure over centuries has deeply modified the environment in Marajó. Therefore, striking evidence of a long human-populated past in this island is in accordance to many other sites throughout the Amazon plain. The result of a land mammal survey in northeastern Marajó is a clear evidence of past and present human interference in the island. Even though Marajó Island has exalted mammal diversity, it will be much higher if long-term studies are effectively implemented.
\end{abstract}

\section{Keywords}

Mammals, Checklist, Lower Amazon, Marajó Island 


\section{Introduction}

Bordering nearly 49,000 square kilometers, Marajó is one of the largest river islands in the world. Most of the island is subject to tidal or seasonal flooding [1]. The local climate can be characterized by two categories: humid tropical, with mean precipitation in the driest month at least $60 \mathrm{~mm}$, and tropical monsoon, with excessive rainfall between January and June. During this period, two thirds of the island is completely flooded [2]-[5]. The annual precipitation ranges between $2500 \mathrm{~mm}$ and $4000 \mathrm{~mm}$, with a mean temperature of around $27^{\circ} \mathrm{C}$, and relative humidity bordering on $80 \%$. Rainfall is distributed in two distinct periods, with a pronounced rainy season between December and June, and a dry season between July and November. Despite this rigorous hydrological regime, the vegetation which occupies about $40 \%$ of the island is flooded annually and is referred to as a savanna or flooded grassland [1]-[9].

Long-term interaction between human societies and the environment has found a prodigal field study in Marajó Island [7]. As previously reported, the history of human occupation of the island dates from about 5000 years before present, showing a long background, up to the present, of aquatic resource management [5]-[7]. Seasonally, flooded savannas as a natural fish nursery were from time to time and successfully managed in order to feed indigenous and subsequently early settlers [5]-[7]. The peak of the fishing economy occurred during an archaeological period known as the Marajoara Phase (400-1350 AD), which featured archaeologically known societies that built mounds and dams as part of efficient hydraulic systems, with the underlying purpose of controlling aquatic fauna and water supplies [7]. Such systems, altered during centuries of manipulation, have persisted to the present, even if they have been affected negatively by the interference of cattle, buffalo and horse ranching [4]-[9].

Despite its historical, cultural and geographical importance, Marajó Island remains relatively less investigated in terms of mammal diversity, ecology and community structure than the rest of the Amazon. Early investigations were carried out by naturalists at the end of the 19th century and the beginning of the 20th century [10]. There has been an effort to collect in the region in the last decades and specimens have been deposited in the mammals' collection of Museu Nacional, Rio de Janeiro and Museu Paraense Emílio Goeldi, in Belém. Despite such efforts, only in the last decade some mammal species have been recorded for the first time in the Marajó Island. Still, some unresolved questions on the occurrence of two primate species [11] [12] and two cervids [11] [13]-[15] remain.

It is remarkable that Marajó Island, specifically its northeast portion and coastline, has been scarcely surveyed in terms of mammal diversity. Hence, faunal inventories in this particular section of the island are sparse, and are mostly restricted to primates and bats [16]-[26]. This scenario has motivated the presentation of this list of land mammals of eastern Marajó Island.

\section{Methods}

We conducted two field surveys in the course of 7-11 December 2012 and 17-25 October 2013 to Jaranduba Farm $\left(0^{\circ} 15^{\prime} 10.20^{\prime \prime} \mathrm{S} ; 048^{\circ} 43^{\prime} 06.34^{\prime \prime} \mathrm{W}\right)$, located on the municipality of Soure, northeast portion of Marajó Island, lower Amazon, Brazil (Figure 1). As both trips were conducted during dry season, unpaved roads and trails could be crossed by a four-wheel vehicle or by foot (Figure 2). Nearby Dunas $\left(0^{\circ} 14^{\prime} 33.47^{\prime \prime S} ; 048^{\circ} 45^{\prime} 27.06^{\prime \prime} \mathrm{W}\right)$ and Ribanceira Farms $\left(0^{\circ} 14^{\prime} 58.09^{\prime \prime S}\right.$; $\left.048^{\circ} 39^{\prime} 13.48^{\prime \prime} \mathrm{W}\right)$ were also visited in search of wild mammal documentation using cameras and recovering carcasses. In addition, a series of interviews were made with native people, born and raised in the area. Information on wild mammal occurrence, habitats and peculiarities was asked to experienced ranchers and former hunters. It should be mentioned that interviews were made spontaneously and relaxed. Only the most reliable answers were selected and double-checked in the second trip. A total of 12 high-quality accounts were accepted and provided the very first checklist of land mammals of northeast Marajó Island. Thus, the list presented here combines voucher specimens deposited in the Museu Paraense Emílio Goeldi (MPEG), cross-checked with citations in historical and current literature, in addition to folk information.

\section{Results}

A total of 23 large and medium-sized land mammal species were recorded in the study area. Table 1 lists specimens recovered and deposited in the MPEG mammal collection along with supporting literature for their general occurrence in Marajó Island. An additional list is presented and includes folk documentation of mammal attributes and other conspicuous information as provided by interviewed residents (Table 2). Brief information on the voucher specimens assembled during our expeditions and deposited in MPEG is presented as follows: 


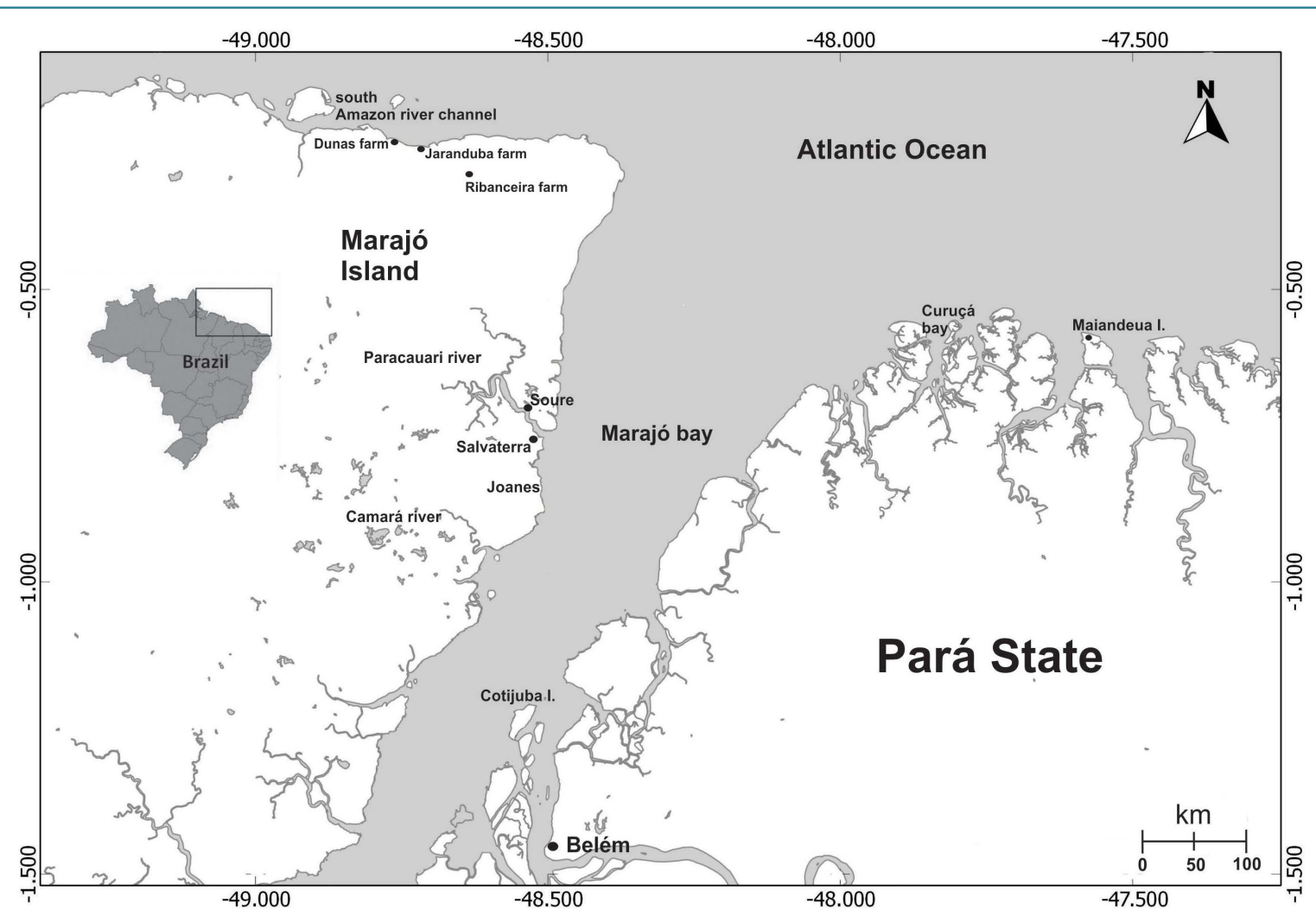

Figure 1. Locations of Jaranduba, Dunas and Ribanceira farms, eastern Marajó Island, lower Amazon, Brazil.

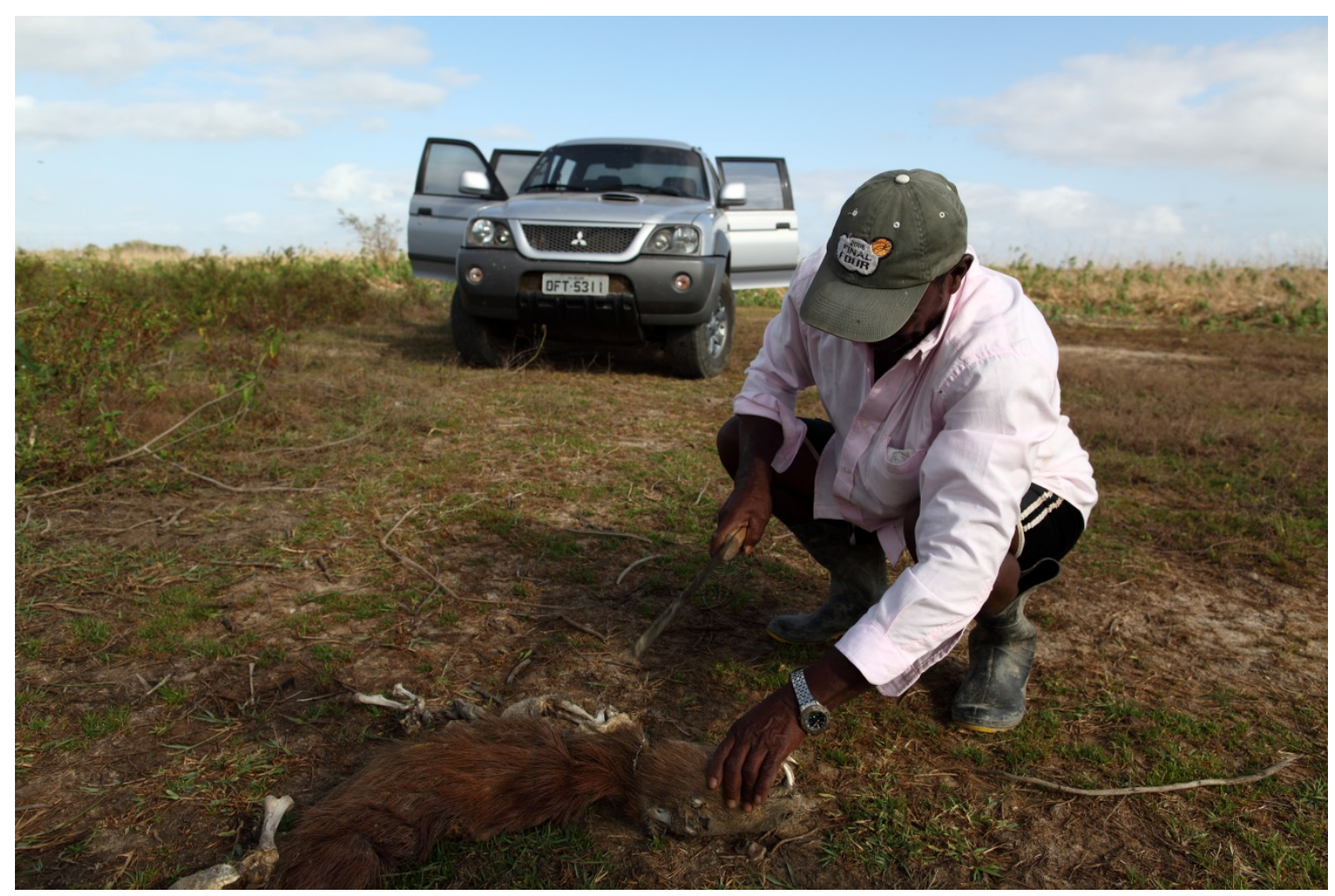

Figure 2. Carcass of a capybara (Hydrochoerus hydrochaeris) found in Jaranduba farm, Marajó Island, Pará, Brazil, in October 2013. Note the dry vegetation on the back and soil condition. Photo by Rodrigo Baleia. 
Table 1. List of large and medium sized mammal specimens recovered during expeditions to Jaranduba, Dunas and Ribanceira Farms in 2012 and 2013, deposited in the Museu Paraense Emílio Goeldi collection, along with supporting literature for their general occurrence in Marajó Island, Brazil.

\begin{tabular}{|c|c|c|c|c|}
\hline $\begin{array}{l}\text { Taxonomic list of } \\
\text { non volant mammals }\end{array}$ & $\begin{array}{c}\text { Common name } \\
\text { (in bold are local names) }\end{array}$ & $\begin{array}{l}\text { Jaranduba, Dunas } \\
\text { and Ribanceira } \\
\text { Farms occurrence }\end{array}$ & $\begin{array}{l}\text { Literature cited } \\
\text { for Marajó Island }\end{array}$ & $\begin{array}{l}\text { Voucher } \\
\text { specimens }\end{array}$ \\
\hline \multicolumn{5}{|l|}{ Didelphimorphia } \\
\hline \multicolumn{5}{|l|}{ Didelphidae } \\
\hline \multicolumn{5}{|l|}{ Didelphis } \\
\hline Didelphis marsupialis & mucura, mucura-preta & $\mathrm{C}, \mathrm{R}$ & [16] [26] [36] [37] [39] & $\begin{array}{l}\text { MPEG } 41027, \\
\text { MPEG } 43005\end{array}$ \\
\hline \multicolumn{5}{|l|}{ Cingulata } \\
\hline \multicolumn{5}{|l|}{ Dasypodidae } \\
\hline \multicolumn{5}{|l|}{ Dasypus } \\
\hline Dasypus novemcinctus & tatu & $\mathrm{C}, \mathrm{R}$ & [16] [26] [34] [35] [39] & $\begin{array}{c}\text { MPEG } \\
43001-43003\end{array}$ \\
\hline Dasypus septemcinctus & $\begin{array}{l}\text { tatuí, tatu-galinha-pequeno, } \\
\text { tatu-marajoara }\end{array}$ & $\mathrm{R}$ & {$[16][26]$} & \\
\hline Dasypus kappleri & tatu-bola & $\mathrm{R}$ & & \\
\hline \multicolumn{5}{|l|}{ Pilosa } \\
\hline \multicolumn{5}{|l|}{ Myrmecophagidae } \\
\hline \multicolumn{5}{|l|}{ Myrmecophaga } \\
\hline Myrmecophaga tridactyla & tamanduá-bandeira & $\mathrm{R}$ & [16] [36] [39] & \\
\hline \multicolumn{5}{|l|}{ Tamandua } \\
\hline Tamandua tetradactyla & $\begin{array}{l}\text { mambira, tamanduá, } \\
\text { tamanduá-colete, } \\
\text { tamanduá-mirim }\end{array}$ & $\mathrm{R}$ & [16] [26] [34] [39] & \\
\hline \multicolumn{5}{|l|}{ Primates } \\
\hline \multicolumn{5}{|l|}{ Cebidae } \\
\hline \multicolumn{5}{|l|}{ Saimiri } \\
\hline Saimiri collinsi & $\begin{array}{l}\text { macaco-de-cheiro, } \\
\text { macaquinho-de-cheiro }\end{array}$ & $\mathrm{C}, \mathrm{R}, \mathrm{O}$ & $\begin{array}{c}{[16][17][19][22]} \\
{[25][26][36][37][39]}\end{array}$ & $\begin{array}{c}\text { MPEG } \\
42166-42168\end{array}$ \\
\hline \multicolumn{5}{|l|}{ Sapajus } \\
\hline Sapajus apella & macaco-prego & $\mathrm{R}$ & $\begin{array}{c}{[16][17][19]} \\
{[23][26][36][37]}\end{array}$ & \\
\hline \multicolumn{5}{|l|}{ Aotidae } \\
\hline \multicolumn{5}{|l|}{ Aotus } \\
\hline Aotus infulatus & macaco-da-noite, quatro-olhos & $\mathrm{R}$ & [16] [19] [21] [26] [39] & \\
\hline \multicolumn{5}{|l|}{ Atelidae } \\
\hline \multicolumn{5}{|l|}{ Alouatta } \\
\hline Alouatta belzebul & guariba & $\mathrm{R}, \mathrm{O}, \mathrm{L}$ & [16]-[20] [26] [34] [39] & \\
\hline \multicolumn{5}{|l|}{ Carnivora } \\
\hline Canidae & & & & \\
\hline
\end{tabular}




\section{Continued}

\begin{tabular}{|c|c|c|c|c|}
\hline \multicolumn{5}{|l|}{ Cerdocyon } \\
\hline Cerdocyon thous & raposa & $\mathrm{C}, \mathrm{R}, \mathrm{O}$ & {$[34]$} & MPEG 43004 \\
\hline \multicolumn{5}{|l|}{ Procyonidae } \\
\hline \multicolumn{5}{|l|}{ Nasua } \\
\hline Nasua nasua & $\begin{array}{c}\text { quati, coati, } \\
\text { quati-de-bando, quati-mundé }\end{array}$ & $\mathrm{R}, \mathrm{O}, \mathrm{L}$ & {$[16][26][34]$} & \\
\hline \multicolumn{5}{|l|}{ Procyon } \\
\hline Procyon cancrivorus & guaxinim, mão-pelada & $\mathrm{O}, \mathrm{R}$ & [16] [26] [34] [36] [37] & $\begin{array}{c}\text { MPEG 25393, } \\
\text { MPEG } 3256\end{array}$ \\
\hline \multicolumn{5}{|l|}{ Lontra } \\
\hline $\begin{array}{c}\text { Lontra longicaudis } \\
\text { Pteronura }\end{array}$ & \multicolumn{3}{|c|}{ Pteronura } & \\
\hline \multicolumn{5}{|l|}{ Felidae } \\
\hline \multicolumn{5}{|l|}{ Leopardus } \\
\hline Leopardus pardalis & jaguatirica, gato-maracajá & $\mathrm{R}$ & {$[16][26][34][39]$} & \\
\hline \multicolumn{5}{|l|}{ Panthera } \\
\hline \multicolumn{5}{|l|}{ Cervidae } \\
\hline \multicolumn{5}{|l|}{ Mazama } \\
\hline Mazama americana & veado-vermelho, veado & $\mathrm{R}$ & [16] [26] [34] [35] [39] & \\
\hline \multicolumn{5}{|l|}{ Ozotoceros } \\
\hline Ozotoceros bezoarticus & veado-campeiro & $\mathrm{R}$ & {$[8][11][14][35]$} & \\
\hline \multicolumn{5}{|l|}{ Rodentia } \\
\hline \multicolumn{5}{|l|}{ Echimyidae } \\
\hline \multicolumn{5}{|l|}{ Proechimys } \\
\hline Proechimys sp. & rato-avermelhado, rato-soiá & $\mathrm{R}$ & [16] [26] & \\
\hline \multicolumn{5}{|l|}{ Hydrochaeridae } \\
\hline \multicolumn{5}{|l|}{ Hydrochoerus } \\
\hline $\begin{array}{l}\text { Hydrochoerus } \\
\text { hydrochaeris }\end{array}$ & capivara & $\mathrm{C}, \mathrm{R}, \mathrm{O}$ & [16] [26] [34]-[39] & $\begin{array}{c}\text { MPEG } \\
42998-43000\end{array}$ \\
\hline \multicolumn{5}{|l|}{ Cuniculidae } \\
\hline \multicolumn{5}{|l|}{ Cuniculus } \\
\hline Cuniculus paca & paca & $\mathrm{R}$ & {$[16][26][34]-[39]$} & \\
\hline \multicolumn{5}{|l|}{ Dasyproctidae } \\
\hline \multicolumn{5}{|l|}{ Dasyprocta } \\
\hline Dasyprocta cf. croconota & cotia-vermelha, cotia & $\mathrm{O}, \mathrm{R}$ & {$[16][26][34][39]$} & \\
\hline & $\mathrm{C}=$ Collected $; \mathbf{O}=$ Obser & Listened; & orted & \\
\hline
\end{tabular}


Table 2. Folk information on the occurrence of land mammals in Jaranduba, Dunas and Ribanceira Farms, Eastern Marajó Island, Brazil.

\begin{tabular}{|c|c|}
\hline $\begin{array}{l}\text { Mammals reported in } \\
\text { eastern Marajó Island }\end{array}$ & $\begin{array}{l}\text { Folk information on mammal occurrence in Jaranduba, } \\
\text { Dunas and Ribanceira Farms, eastern Marajó Island }\end{array}$ \\
\hline Dasypus septemcinctus & Smaller than the other, walk along the night \\
\hline Dasypus kappleri & Possibly known as "tatu-bola". Larger than the other \\
\hline Myrmecophaga tridactyla & I saw one passing by my house (Retiro São Geraldo, Ribanceira) \\
\hline Tamandua tetradactyla & They can be found in the "tesos" \\
\hline Alouatta belzebul & They are very noisy \\
\hline Aotus infulatus & Certain time I shot one thinking it was something else \\
\hline Sapajus apella & It is rare here (Retiro São Geraldo, Ribanceira) \\
\hline Saimiri collinsi & They are very common \\
\hline Cerdocyon thous & It is like a fox, very smart, nocturnal \\
\hline Nasua nasua & Like to live in the "teso". Quati-mundé is the old male, solitary \\
\hline Procyon cancrivorus & Live usually close to the water \\
\hline Lontra longicaudis & Occurs in the igarapé do Siriri, Jaranduba Farm \\
\hline Pteronura brasiliensis & I have seen one far away, on the way to Dunas Farm (Jaranduba) \\
\hline Leopardus pardalis & It attacks and kills the chickens \\
\hline Panthera onca & It is rare around here \\
\hline Mazama americana & Once they were very abundant \\
\hline Ozotoceros bezoarticus & Occurs in the fields during high waters, has a white tail \\
\hline Proechimys sp. & Lives in trees: "dá trepado". Fur is very red: "pelagem bem vermelha" \\
\hline Hydrochoerus hydrochaeris & $\begin{array}{l}\text { Lives only in the fields (Retiro Caju, Jaranduba). I take care of one } \\
\text { newborn that was abandoned by its mother (Retiro São Geraldo, Ribanceira) }\end{array}$ \\
\hline Dasyprocta leporina & It is very yellowish in color \\
\hline
\end{tabular}

Common Opossum (Didelphis marsupialis): one skull found on a sandy beach in Ribanceira Farm on 9 December 2012. The presence of "mucuras" was reported in all visited sites.

Nine-banded armadillo (Dasypus novemcinctus): three specimens of nine-banded armadillo (Dasypus novemcinctus) were found in Jaranduba Farm on 10 and 11 December 2012. Armadillos were reported to be fairly common in all sites visited.

Squirrel monkey (Saimiri collinsi): a fairly common species in the "tesos" and along the coastal stretch of vegetation in Jaranduba and Ribanceira Farms. In October 2013, large groups of squirrel monkeys of up to 20 - 25 individuals were sighted in Ribanceira Farm hanging on mango trees. Saimiri collinsi is a primate species just recently revalidated [24] [25].

Crab-eating fox (Cerdocyon thous): a pair of crab-eating foxes was sighted on 10 December 2012 at nightfall while returning from Mocambo Farm. On 11 December 2012 a carcass was found on the road to Retiro Pindoba and saved as reference material. We consider these records of particular interest as little is known on the biogeography and ecology of crab-eating fox in Marajó Island and eastern Amazon in general [27] [28].

Capybara (Hydrochoerus hydrochaeris): the capybara is the largest living rodent, with adults weighing 49 $50 \mathrm{~kg}$ (range 35 - 65) [29]. This large mammal has long been reported to inhabit the grasslands of Marajó Island [10] [30] [31]. Indeed, capybaras were commonly sighted during the two field campaigns. Not surprisingly, carcasses were easily found and skulls were collected on both expeditions (Figure 2). A severe drought and salinization of the fields was observed in the 2012 field campaign. According to locals, by the end of the dry season, capybaras were forced to drink salted water, soon became weak and many perished. We noted several emaciated capybaras and some seemed to be roaming in the fields in search of water or a wetter location. A captive small capybara was found in Ribanceira Farm in October 2013 (Figure 3). 


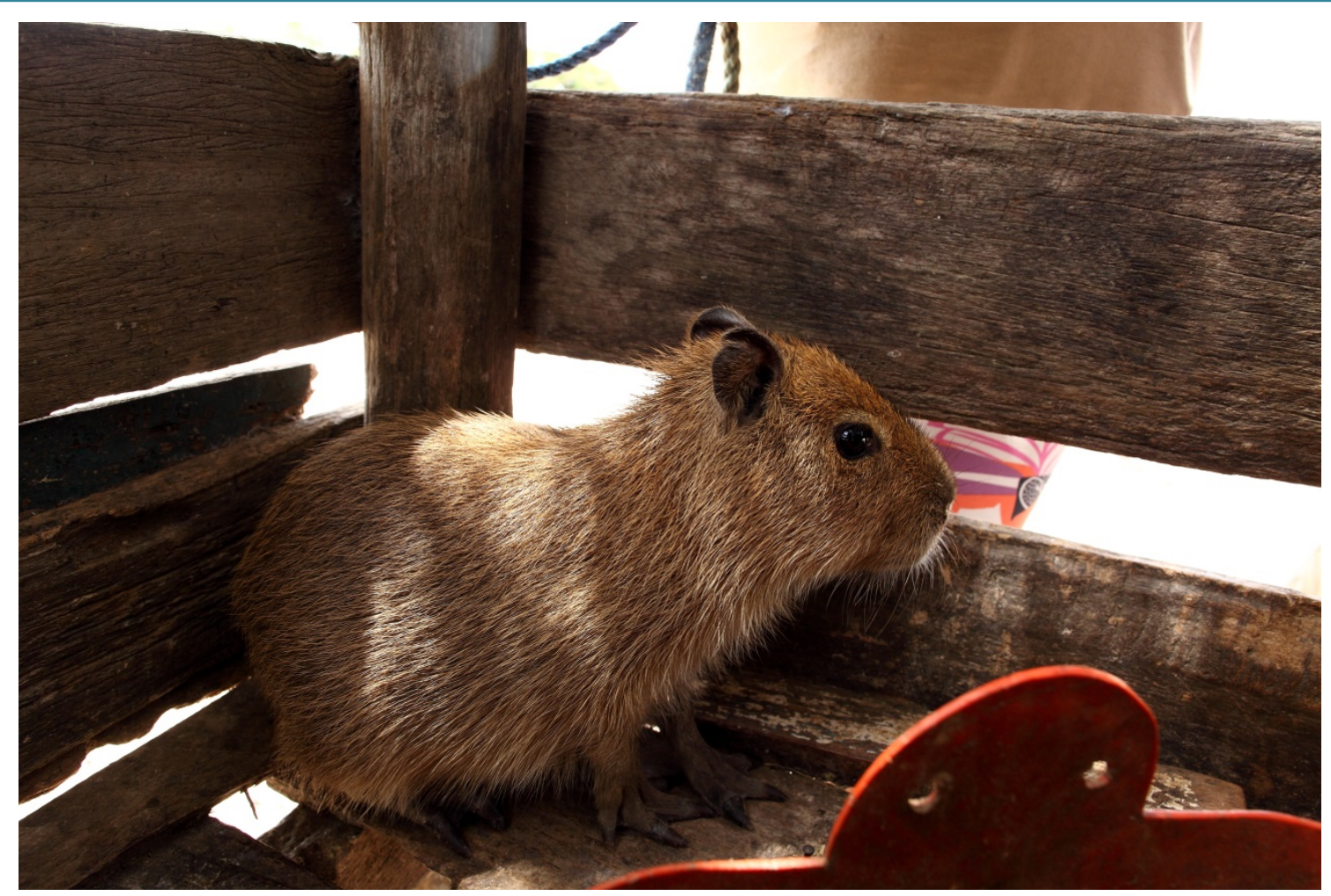

Figure 3. Young capybara (Hydrochoerus hydrochaeris) kept in Ribanceira Farm, Marajó Island, Pará, Brazil in October, 2013. Photo by Rodrigo Baleia.

\section{Discussion}

Humans have occupied Marajó Island for at least the past five to seven thousand years [32] [33]. These first inhabitants probably subsisted on fish and game hunting and small-scale agriculture [7]. It has been generally reported that cultivation would have been limited in recent times by the low fertility of the land and their inadequate drainage [5]-[7]. As early as the Seventieth Century cattle ranching has spread out in the fields of Marajó and has since grown to over a million cows and water buffaloes and one hundred thousand horses by 1990 [34] [35]. This immense herd causes severe impacts on the soil and the environment by consequence [34]-[39].

In effect, during our expeditions, domestic pigs, along with cattle, buffaloes, horses and mules, were the most commonly sighted large mammals in the grasslands of Marajó Island. While buffaloes were usually confined to remaining pools (Figure 4), pigs, in contrast, seem to do well during the dry season. Piglets were found elsewhere, often approaching the houses in search of extra food, indicating reproduction success even at this time of year. Domestic dogs (Canis lupus familiaris) are used to protect houses from invading pigs. Related to this, domestic cats (Felis catus) are used to catch mice and bats.

As pointed out by early authors [5] [6], the weight of water buffaloes results in hoofprints of up to $10 \mathrm{~cm}$ in depth [40] which, together with their habit of excavating holes in which they cool themselves during the dry season, provoke significant alterations in the structure of the superficial soil layers and the composition of the vegetation, which favor erosive processes [41]. The compact soil, hardened in the scorching sun, creates an environment unfavorable for plant growth, thus reducing the productivity and longevity of forage species [42]. This is the so called "aterroada", the local designation of the "caboclos" ranchers for such particular condition of the soil. By contrast, in beginning of the rainy season, the aterroada soon become soaked in heavy rain, and cattle have to move to elevated parts. The primitive people of Marajó has learned how to use this condition in favor, creating the "tesos" or "mounds", that could reach $200 \mathrm{~m}$ in length, $30 \mathrm{~m}$ wide and $10 \mathrm{~m}$ in height [43]. The landscape of Jaranduba Farm is a classical combination of aterroadas and tesos, the latter dominated by palms (Astrocaryum vulgare) and cashew trees (Anacardium occidentale). Squirrel monkeys (Saimiri collinsi), capybaras (Hydrochoerus hydrochaeris) and coatis (Nasua nasua) (Figure 5) were observed using the tesos habitat for 


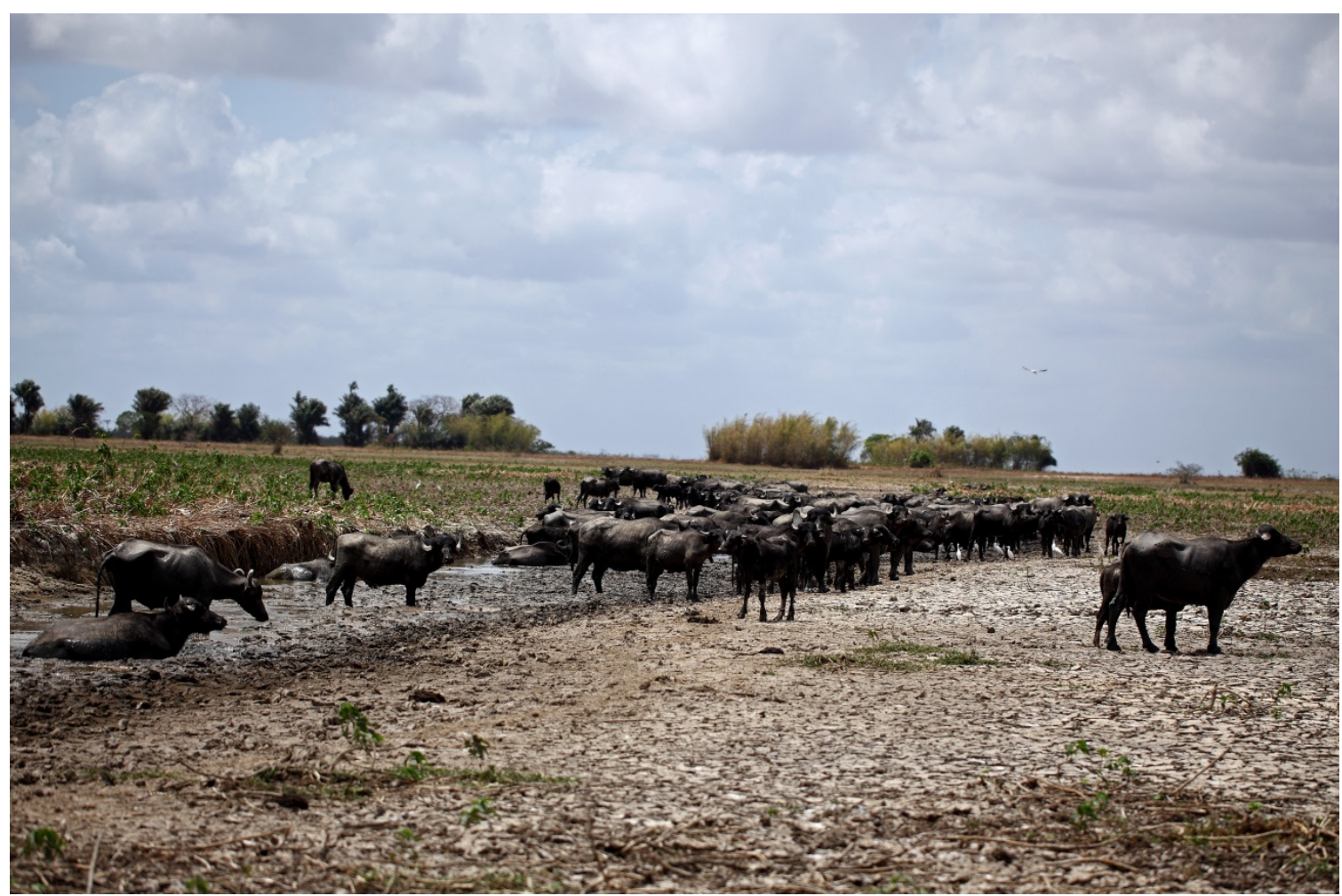

Figure 4. Water Buffaloes cooling in a mud pool during dry season in Jaranduba Farm, Marajó Island, Pará, Brazil. Note the Marajó "tesos" or mounds on the back. Photo by Rodrigo Baleia.

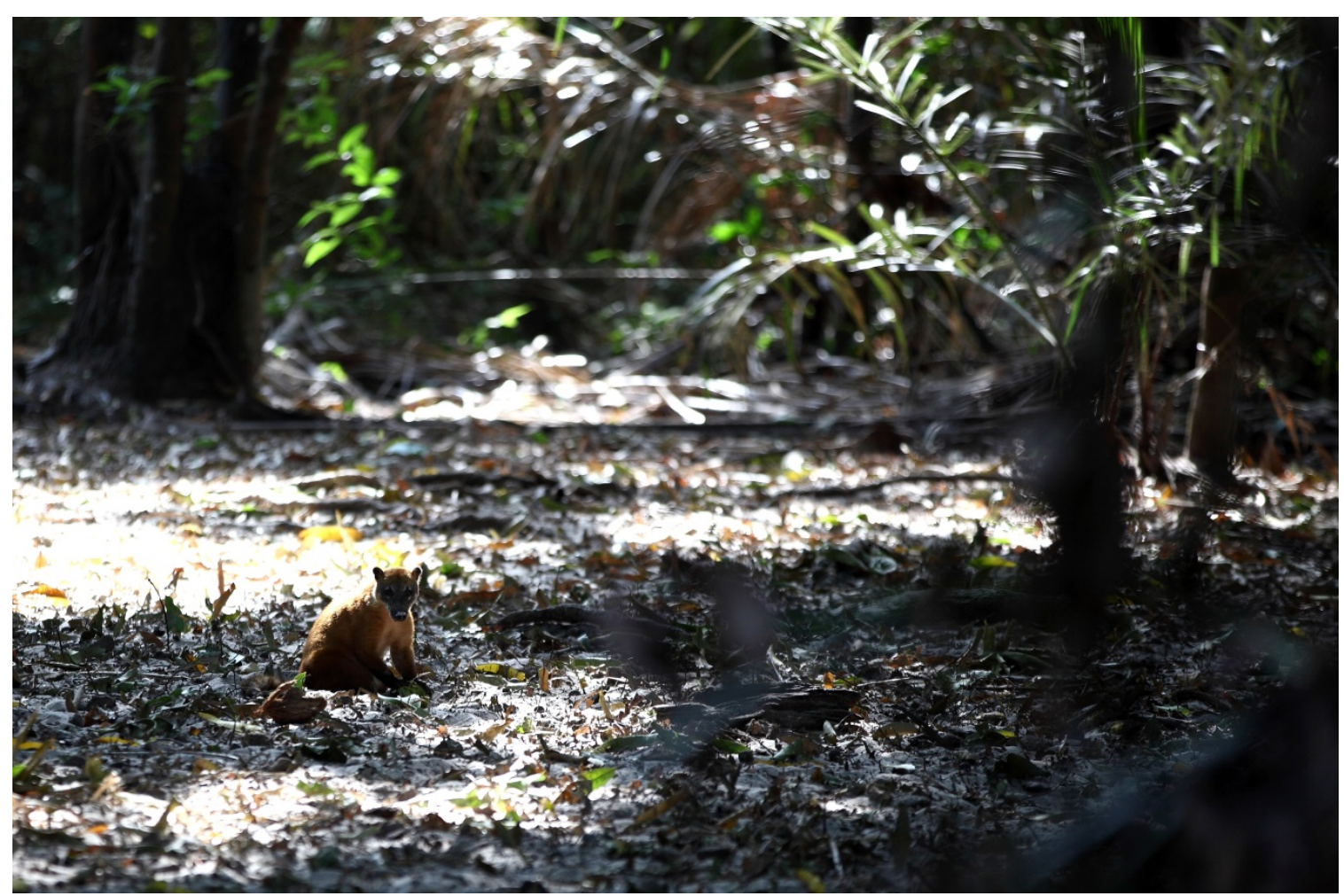

Figure 5. South American Coati (Nasua nasua) visiting mango trees nearby the big house of Jaranduba Farm in October, 2013. Photo by Rodrigo Baleia. 
foraging and shading from sun. Guariba monkeys (Alouatta belzebul) prefer the taller trees, which are usually found closer the coastline. Agoutis (Dasyprocta cf. croconota) were also seen amid the coastal vegetation, as mixture of forest, shrub and planted trees dominate. It is worth saying that our results coincide with a previous survey conducted in 1988 that only reported two primate species (S. collinsi and A. belzebul) in a similar environment in the northeast of Marajó Island [17].

In this sense, the combination of extreme environments, peculiarly compressed soils in the dry season, in contrast to flooded and unstable in the rainy season, is selective for establishment of some wild mammals. This could explain the absence of sloths (Bradypus variegatus and Choloepus didactylus) on Jaranduba and Ribanceira Farms, decidedly cited by locals as non-occurring in the area (In Portuguese: "aqui não tem"), as well as small cats, skunks and some marsupials.

The mammal community of eastern Marajó Island is naturally a result of human pressure directed to every available possibility of use. This includes hunting, practiced for centuries in Marajó Island [22]-[25] as a precondition of daily food income in farms and villages or to be exported as "meat" to Belém. This certainly has been the major cause of decline of the number of many mammal species, including other large desired targets, as caimans and turtles [34] [35]. As such, hunting could be credited as the main reason of local extinctions of peccaries, tapirs and pumas and the decrease of jaguars. As a matter of fact, jaguars and pumas were intensively hunted in Marajó Island, as they are seen as natural killers of cattle [35].

The Marajó archipelago has been designated as a state conservation unit in 1989, covering 5,500,000 square kilometers [44]. Although the Marajó Island has gained this status, it has been postulated that little has been done to advance environmental protection on Marajó archipelago [6].

As mentioned before, most of the eastern part of the island is used for cattle and water buffalo ranching, and the western forests are being heavily logged. Altogether, human pressure over centuries has deeply modified the environment in Marajó Island. Therefore, striking evidence of a long human-populated past in Marajó is in accordance to many other sites throughout the Amazon plain [45]. The result of a land mammal survey in northeastern Marajó is a clear evidence of past and present human interference in the island. Even though, there exist exalted mammal diversity in Marajó Island and, of course, it will be much higher if long-term studies are effectively implemented.

\section{Conclusion}

The northeastern Marajó Island, notably Jaranduba, Dunas and Ribanceira Farms, hosts a representative mammal community, an area lacking previous faunal studies. Our surveys have cataloged a total of 23 large- and medium-sized land mammal species in the study area. We have reached a factual report of long-term presence of men in Marajó Island and its consequent mammal community.

\section{Acknowledgements}

We thank Dr. Ival Lobato, owner of Jaranduba Farm, for his immense hospitality. Special recognition goes to our field assistants: Boca, Haroldo, Seu Tocó, Dona Ruth and Lavinho. Several other folks were of great help, including Seu Alfredo, from Retiro São Geraldo, for his field assistance and reception at Ribanceira Farm and Natinho, from Retiro Caju at Jaranduba Farm, for logistical support. Field trips were supported by Conselho Nacional de Desenvolvimento Científico e Tecnológico-CNPq (Grants No. 552967/2011-4), VALE/FAPESPA/ FAPEMIG (Grants No. 038/2011) and Petrobras (Projeto Bicho D'água: Conservação Socioambiental). GEMAM personnel were of considerable benefit in the field, expressly Jorge A. B. Soares, Jacqueline O. Vieira and Bruna M. L. Martins and, last but not least, thanks to our photographer Rodrigo Baleia, for being so gentle and such a companion in the 2013 field trip.

\section{References}

[1] Goulding, M., Barthem, R. and Ferreira, E. (2003) The Smithsonian Atlas of the Amazon. Smithsonian Books, Washington DC.

[2] Cardoso, E.C. and Pereira, W.L.A. (2002) Mineral Deficiency of Buffaloes from Marajó Island, North of Brazil: Current Situation and Perspectives. I Buffalo Symposium of Americas, Belém.

[3] Lima, A.M.M., Oliveira, L.L., Fontinhas, R.L. and Lima, R.J.S. (2005) Ilha do Marajó: Revisão histórica, hidrocli- 
matologia, bacias hidrográficas e proposta de gestão. Holos Environment, 5, 65-80.

[4] Franzinelli, E. (1990) Evolution of the Geomorphology of the Coast of the State of Pará, Brazil. In: Prost, M.-T., Ed., Évolution des littoraux de Guyane et de la zone Caraïbe Méridionale pendant le Quaternaire, Symposium PICG 274/ ORSTOM, Cayenne, 203-230.

[5] Montag, L.F.A., Albuquerque, A.A., Freitas, T.M.S. and Barthem, R.B. (2009) The Ichthyofauna of Savannas from Marajó Island, State of Pará, Brazil. Biota Neotropica, 9, 241-253. http://dx.doi.org/10.1590/S1676-06032009000300024

[6] Montag, L.F.A., Freitas, T.M.S., Mendes-Oliveira, A.C. and Barthem, R.B. (2011) Environmental Assessment and Aquatic Biodiversity Conservation of Amazonian Savannas, Marajó Island, Brazil. In: Pavlinov, I., Ed., Research in Biodiversity: Models and Applications, InTech Europe, Rijeka, 261-284. http://dx.doi.org/10.5772/22997

[7] Schaan, D. (2010) Long-Term Human Induced Impacts on Marajó Island Landscapes, Amazon Estuary. Diversity, 2, 182-206. http://dx.doi.org/10.3390/d2020182

[8] Rossetti, D.P. and Toledo, P.M. (2006) Biodiversity from a Historical Geology Perspective: A Case Study from Marajó Island, Lower Amazon. Geobiology, 4, 215-223. http://dx.doi.org/10.1111/j.1472-4669.2006.00080.x

[9] Barthem, R.B. and Fabré, N.N. (2003) Biologia e diversidade dos recursos pesqueiros da Amazônia. In: Rufino, M.L., Ed., A pesca e os recursos pesqueiros na Amazônia brasileira, Pro-Várzea, Manaus, 11-55.

[10] Goeldi, E.A. and Hagmann, G. (1904) Pródromo de um catálogo crítico e comentado da coleção de mamíferos no Museu do Pará (1894-1903). Boletim do Museu Paraense de História Natural e Ethnographia, 4, 38-122.

[11] Silva Júnior, J.S., Marques-Aguiar, S.A., Aguiar, G.F.S., Saldanha, L.N., Avelar, A.A. and Lima, E.M. (2005) Mastofauna não voadora das savanas do Marajó. In: de Resumos do III., L., Ed., Sociedade Brasileira de Zoologia, Congresso Brasileiro de Zoologia, Aracruz, 131.

[12] Fonsêca da Silva, V. (2012) Variação morfológica e molecular dos sagüis de face com pêlos da Amazônia oriental, Saguinus midas (Linnaeus, 1758) e Saguinus niger (É. Geoffroy, 1803). Dissertation, Programa de Pós Graduação em Zoologia, Museu Paraense Emílio Goeldi/Universidade Federal do Pará, Belém

[13] Black, P. and Vogliotti, A. (2008) Mazama gouazoubira. In: IUCN 2013. IUCN Red List of Threatened Species. Version 2013.1. www.iucnredlist.org

[14] González, S., Cosse, M., Braga, F.G., Vila, A.R., Merino, M.L., Dellafiore, C., Cartes, J.L., Maffei, L. and Dixon, M.G. (2010) Pampas Deer Ozotoceros bezoarticus (Linnaeus, 1758). In: Duarte, J.M.B. and Gonzalez, S., Eds., Neotropical Cervidology: Biology and Medicine of Latin American Deer, Funep/IUCN, Jaboticabal, 119-132.

[15] Black-Décima, P., Rossi, R.V., Vogliotti, A., Cartes, J.L., Maffei, L., Duarte, J.M.B., González, S. and Juliá, J.P. (2010) Brown Brocket Deer Mazama gouazoubira (Fischer, 1814). In: Duarte, J.M.B. and Gonzalez, S., Eds., Neotropical Cervidology: Biology and Medicine of Latin American Deer, Funep/IUCN, Jaboticabal, 190-201.

[16] Silva Júnior, J.S., Ohana, J.A.B., Regina Silva, C., Cardoso, E.M., Avelar, A.A., Fonsêca da Silva, V. and Sousa Silva, L. (2011) Mamíferos terrestres de médio e grande porte do litoral da Amazônia brasileira. In: Pessôa, L.M., Tavares, W.C. and Siciliano, S., Eds., Mamíferos de Restingas e Manguezais do Brasil, Sociedade Brasileira de Mastozoologia, Rio de Janeiro, 19-44.

[17] Ayres, J.M., Bonsiepe, J.I. and Townshend, T.J. (1989) Notes on Monkeys and Habitat in the Northeast Marajó Island, Brazil. Primate Conservation, 10, 21-22.

[18] Fernandes, M.E.B. (1994) Notes on the Geographic Distribution of Howling Monkeys in the Marajó Archipelago, Pará. Brazil. International Journal of Primatology, 15, 919-926. http://dx.doi.org/10.1007/BF02736077

[19] Fernandes, M.E.B., Silva, J.M.C. and Silva Júnior, J.S. (1995) The Monkeys of the Islands of the Amazon Estuary, Brazil: A Biogeographic Analysis. Mammalia, 59, 213-221. http://dx.doi.org/10.1515/mamm.1995.59.2.213

[20] Gregorin, R. (2006) Taxonomia e variação geográfica das espécies do gênero Alouatta Lacépède (Primates, Atelidae) no Brasil. Revista Brasileira de Zoologia, 23, 64-144. http://dx.doi.org/10.1590/S0101-81752006000100005

[21] Hershkovitz, P. (1983) Two New Species of Night Monkeys, Genus Aotus (Cebidae, Platyrrhini): A Preliminary Report on Aotus Taxonomy. American Journal of Primatology, 4, 209-243. http://dx.doi.org/10.1002/ajp.1350040302

[22] Hershkovitz, P. (1984) Taxonomy of the Squirrel Monkey Genus Saimiri (Cebidae, Platyrrhini): A Preliminary Report with Description of a Hitherto Unnamed Form. American Journal of Primatology, 7, 55-210. http://dx.doi.org/10.1002/ajp.1350070212

[23] Silva Júnior, J.S. (2001) Especiação nos macacos-prego e caiararas, gênero Cebus Erxleben, 1777 (Primates, Cebidae). Ph.D. Dissertation, Programa de Pós-Graduação em Genética, Universidade Federal do Rio de Janeiro, Rio de Janeiro.

[24] Lavergne, A., Ruiz-García, M., Catzeflis, F., Lacote, S., Contamin, H., Mercereau-Puijalon, O., Lacoste, V. and de Thoisy, B. (2010) Phylogeny and Phylogeography of Squirrel Monkey (Genus Saimiri) Based on Cytochrome $b$ Genetic Analysis. American Journal of Primatology, 72, 242-253. http://dx.doi.org/10.1002/ajp.20773 
[25] Mercês, M.R. (2013) Variação morfológica e molecular nos macacos-de-cheiro (Gênero Saimiri Voigt, 1831) da Amazônia oriental. Dissertation, Programa de Pós Graduação em Zoologia, Museu Paraense Emílio Goeldi/Universidade Federal do Pará, Belém.

[26] Marques-Aguiar, S.A., Melo, C.C.S., Aguiar, G.F.S. and Queiróz, J.A.L. (2002) Levantamento preliminar da mastofauna da região de Anajás-Muaná, Ilha de Marajó, Pará, Brasil. Revista Brasileira de Zoologia, 19, 841-854. http://dx.doi.org/10.1590/S0101-81752002000300022

[27] Machado, F.A. and Hingst-Zaher, E. (2009) Investigating South American Biogeographic History Using Patterns of Skull Shape Variation on Cerdocyon thous (Mammalia: Canidae). Biological Journal of the Linnean Society, 98, 77-84. http://dx.doi.org/10.1111/j.1095-8312.2009.01274.x

[28] Emmons, L.H. (1997) Neotropical Rainforest Mammals: A Field Guide. 2nd Edition, the University of Chicago Press, Chicago and London.

[29] Moreira, J.R., Alvarez, M.R., Tarifa, T., Pacheco, V., Taber, A., Tirira, D.G., Herrera, E.A., Ferraz, K.M.P.M.B., Aldana-Domínguez, J. and MacDonald, D.W. (2013) Taxonomy, Natural History and Distribution of the Capybara. In: Moreira, J.R., Ferraz, K.M.P.M.B., Herrera, E.A. and Macdonald, D.W., Eds., Capybara: Biology, Use and Conservation of an Exceptional Neotropical Species, Springer Science+Business Media, New York, 3-37. http://dx.doi.org/10.1007/978-1-4614-4000-0_ _

[30] Goeldi, E.A. (1899) Maravilhas da natureza na ilha de Marajó (Rio Amazonas). Boletim do Museu Paraense de História Natural e Ethnographia, 3, 370-400.

[31] Cott, H.B. (1926) Observations on the Life-Habits of Some Batrachians and Reptiles from the Lower Amazon: And a Note on Some Mammals from Marajó Island. Proceedings of the Zoological Society of London, 96, 1159-1178. http://dx.doi.org/10.1111/j.1096-3642.1926.tb02240.x

[32] Simões, M.F. (1981) Coletores-Pescadores Ceramistas do Litoral do Salgado (Pará). Boletimdo Museu Paraense Emílio Goeldi, Série Antropologia, 7, 1-31.

[33] Roosevelt, A.C., Housley, R.A., Imazio da Silveira, M., Maranca, S. and Johnson, R. (1991) Eighth Millennium Pottery from a Prehistoric Shell Midden in the Brazilian Amazon. Science, 254, 1557-1696. http://dx.doi.org/10.1126/science.254.5038.1621

[34] Teixeira, J.F. (1953) O Arquipélago de Marajó. Serviço Gráfico do Instituto Brasileiro de Geografia e Estatística, Rio de Janeiro.

[35] Barroso, A.E.V. (1954) Marajó: Estudo etnográfico, geológico, histórico sobre a grandiosa ilha da foz do Amazonas. Biblioteca do Exército Editora, Rio de Janeiro.

[36] Miranda Neto, M.J. (1968) A Foz do Rio-Mar: Subsídios para o desenvolvimento de Marajó. Distribuidora Record de Serviços de Imprensa Ltda., Rio de Janeiro.

[37] Neto, M. (1993) Marajó desafio da Amazônia: Aspectos da reação a modelos exógenos de desenvolvimento. Edições Cejup, Belém.

[38] Gallo, G. (1997) Marajó, a ditadura da água. Edições “O Museu do Marajó”, Cachoeira do Arari, Pará.

[39] Lisboa, P.L.B. (2012) A Terra dos Aruãs: Uma história ecológica do arquipélago do Marajó. Museu Paraense Emílio Goeldi, Belém.

[40] Santos, V.F. (2006) Ambientes costeiros amazônicos: Avaliação de modificações por sensoriamento remoto. Ph.D. Dissertation, Universidade Federal Fluminense, Rio de Janeiro.

[41] Dias, M.C.O. (1999) Manual de impactos ambientais: Orientações básicas sobre aspectos ambientais de atividades produtivas. Banco do Nordeste, Fortaleza.

[42] Imhoff, S., Silva, A.P. and Tormena, C.A. (2000) Aplicações da curva de resistência no controlede qualidade física de um solo de pastagem. Pesquisa Agropecuária Brasileira, 35, 1493-1500. http://dx.doi.org/10.1590/S0100-204X2000000700025

[43] Reis e Silva, H. (2014) Os Tesos de Marajó. http://www.gentedeopiniao.com.br/lerConteudo.php?news=128143

[44] SEMA (2014) Plano de Manejo da APA Marajó está em fase de zoneamento ecológico. http://www.sema.pa.gov.br/2014/09/30/plano-de-manejo-da-apa-marajo-esta-em-fase-de-zoneamento-ecologico/

[45] Clement, C.R. and Junqueira, A.B. (2010) Between a Pristine Myth and an Impoverished Future. Biotropica, 42, 534536. http://dx.doi.org/10.1111/j.1744-7429.2010.00674.x 
Scientific Research Publishing (SCIRP) is one of the largest Open Access journal publishers. It is currently publishing more than 200 open access, online, peer-reviewed journals covering a wide range of academic disciplines. SCIRP serves the worldwide academic communities and contributes to the progress and application of science with its publication.

Other selected journals from SCIRP are listed as below. Submit your manuscript to us via either submit@scirp.org or Online Submission Portal.
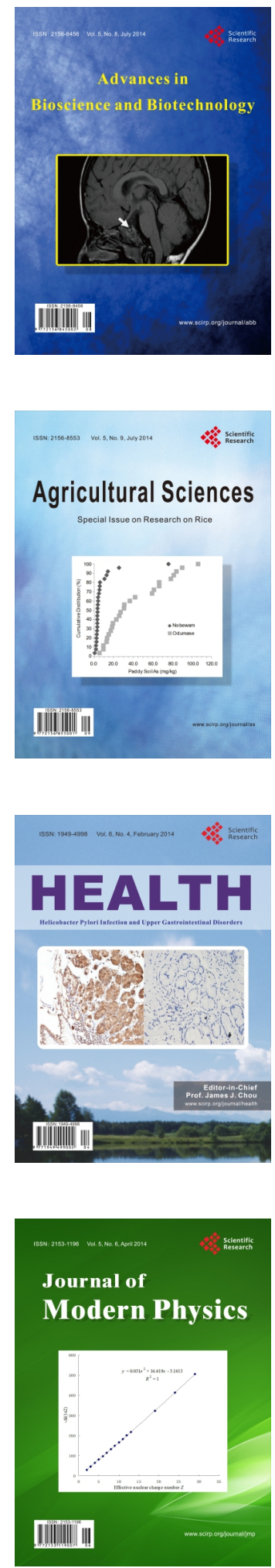
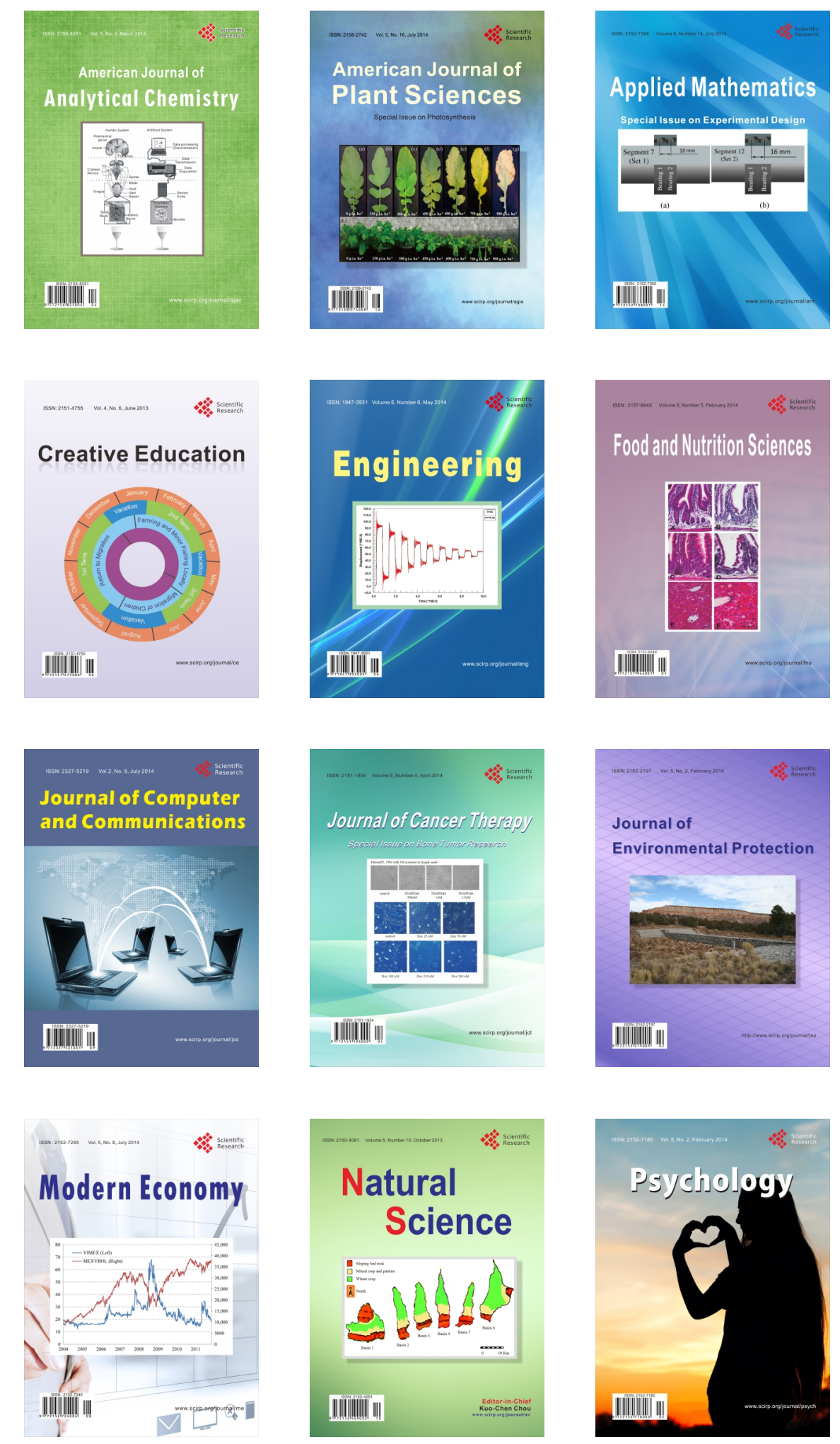